\title{
ANALISIS FAKTOR-FAKTOR YANG MEMPENGARUHI PENDAPATAN USAHATANI SORGUM DI KABUPATEN GUNUNGKIDUL
}

\author{
Analysis of Factors Affecting Sorghum Farming Income \\ In Gunungkidul Regency \\ Retno Wisti Gupito ${ }^{1}$, Irham $^{2)}$, Lestari Rahayu Waluyati ${ }^{2)}$ \\ ${ }^{1)}$ Jurusan Sosial Ekonomi Pertanian, Fakultas Pertanian, Universitas Gadjah Mada \\ ${ }^{2)}$ Fakultas Pertanian, Universitas Gadjah Mada
}

\begin{abstract}
The objective of this study are : (1) to understand about the contribution of sorghum farming income to total household income, (2) factors that influence sorghum farming income, and (3) income distribution level of sorghum farmers in Gunungkidul Regency.The basic methodused in this studyis descriptive-analytic. Sampling method used in this study is purposive sampling. The data weretaken from 30 farmers in study area. The data was collected by an interview,questionnaires and literatures study case.In order to learn the several factors influencing income level, isused multiple linear regression method.On the other hand, the level of total income distribution of sorghum farmerswas analylizedby using Gini Ratio and Lorenz Curve. The results of this study showsthat shorgum farming incomecontributes $2 \%$ for total farmers income. This study also show that sorghum farming does not cause inequality income in the study area. Several factorsthat affect sorghum farmers income positively are the land size and seed prices.
\end{abstract}

Keywords : distribution, Gini Ratio,Lorenz Curve, farm income, sorghum

\section{INTISARI}

Penelitian ini bertujuan untuk : (1) mengetahui kontribusi pendapatan usahatani sorgum pada pendapatan total petani, (2) mengetahui faktor-faktor yang mempengaruhi tingkat pendapatan petani sorgum serta (3) tingkat ketimpangan distribusi pendapatan total petani sorgum di Kabupaten Gunungkidul. Metode dasar yang digunakan dalam penelitian ini adalah deskriptif-analitis sedangkan metode pengambilan sampel yang digunakan adalah purposif (purposive sampling method). Jenis data adalah data primer yang diperoleh dari 30 petani responden di daerah penelitian. Pengumpulan data dilakukan dengan teknik wawancara, kuisioner, dan studi pustaka. Untuk mengetahui faktor-faktor yang mempengaruhi tingkat pendapatan petani sorgum dilakukan analisis regresi linear berganda (multiple linear regression method) sedangkan untuk mengetahui tingkat ketimpangan distribusi pendapatan total petani sorgum di Kabupaten Gunungkidul dianalisis dengan koefisien gini dan kurva lorenz. Hasil penelitian menunjukkan bahwa usahatani sorgum berkontribusi sebesar $2 \%$ terhadap pendapatan total petani. Usahatani sorgum tidak menyebabkan ketimpangan pendapatan di lokasi penelitian. Faktor-faktor yang mempengaruhi tingkat pendapatan petani sorgum secara positif adalah luas lahan dan harga bibit.

Kata kunci : distribusi, Indeks Gini, Kurva Lorenz, pendapatan usahatani, sorgum

\section{PENDAHULUAN}

Sorgum merupakan salah satu jenis tanaman serealia yang memiliki potensi besar untuk dikembangkan di Indonesia karena memiliki daerah adaptasi yang luas. Tanaman sorgum toleran terhadap kekeringan dan genangan air,dapat berproduksi pada lahan marginal, serta relatif tahan terhadap gangguan hama atau penyakit. Biji sorgum dapat digunakan sebagai bahan pangan serta pakan ternak.

Sorgum merupakan sumber karbohidrat yang cukup potensial karena kandungan karbohidratnya cukup tinggi. Sorgum merupakan komoditas yang diharapkan dapat menggantikan gandum. Sebagai bahan pangan, sorgum ditepungkan untuk bahan roti, kue serta bubur. Di
Indonesia, sorgum dimasak untuk campuran beras, atau dikukus sebagai nasi sorgum. Potensi sorgum untuk industri pakan ternak (pengganti jagung) juga cukup tinggi. Namun, masalah utama penggunaan biji sorgum sebagai bahan pangan maupun pakan adalah kandungan tanin yang cukup tinggi, mencapai $0,40 \%-3,60 \%$ (Rooney dan Sullines 1977). Selama ini popularitas sorgum di kalangan petani, tidak hanya kalah dibanding komoditas padi dan jagung, melainkan juga berada di bawah singkong dan ubi jalar. Produktivitas sorgum rata-rata di tingkat petani kita hanya sekitar 1 ton per hektar per musim tanam. Hasil ini kalah dibanding padi yang rata-rata mencapai 4 ton per hektar dan jagung hibrida yang mampu 
berproduksi sampai 8 ton per hektar per musim tanam.

Secara teknis, sorgum dapat dibudidayakan di Indonesia. Sorgum bisa dibudidayakan di kawasan beriklim tropis, munson, sabana, gurun sampai ke kawasan sub tropis. Di Indonesia, sorgum bisa dikembangkan mulai dari dataran rendah sampai dengan ketinggian sekitar 700 mdpl. Salah satu kelebihan sorgum dibanding dengan padi dan jagung adalah, ia tahan kekeringan.

Di Indonesia, sorgum ditanam hanya sebagai pengisi lahan di musim kemarau. Hasil panen tanaman sorgum yang berupa biji dijual sebagai pakan dan batangnya dimanfaatkan petani untuk memberi makan ternak. Pendapatan yang diterima petani dari menjual biji sorgum pun tidak seberapa. Dikarenakan pengolahan biji sorgum yang sulit dan minimnya pengetahuan masyarakat mengenai multiguna sorgum mengakibatkan popularitas sorgum masih kalah dibanding dengan komoditas lain.

Ketergantungan masyarakat Indonesia terhadap terigu terus meningkat. Hal ini ditandai oleh meningkatnya impor gandum dari tahun ke tahun. Kecuali terigu hanya sorgum yang dapat menghasilkan tepung yang mengandung gluten, sehingga peluang sorgum sebagai substitusi terigu cukup besar. Adanya kemampuan substitusi tersebut akan menghemat penggunaan dan impor tepung terigu. Namun demikian, pengembangan sorgum secara luas mempunyai kendala :

1. belum ada jaminan harga yang layak yang didapatkan.

2. belum ada jaminan pasar yang dapat menampung hasil panen.

3. belum berkelanjutannya kemitraan yang dapat mendukung tersedianya saprodi dan jaminan penampungan hasil pemasaran.

4. nilai usahatani sorgum masih kalah bersaing dengan tanaman lain.

Secara ekonomis sorgum belum begitu teruji apakah ia mampu membawa pelaku usaha tani pada kesejahteraan. Kendala utama pengembangan sorgum di masyarakat adalah, sulitnya mengolah malai dan gabah menjadi "beras sorgum". Upaya perontokan dan penumbukan secara tradisional, maupun dengan mesin penggiling padi, menghasilkan beras sorgum yang masih belum bersih dari kulit. Akibatnya, apabila dilakukan penepungan, kulit biji akan terikut. Mutu tepung demikian sangat jelek karena kalau dimasak akan menghasilkan rasa pahit atau sepet. Inilah mengapa petani lebih memilih menanam jagung dan kedelai daripada menanam sorgum.

\section{LANDASAN TEORI}

Sorgum adalah jenis serealia yang di Indonesia belum banyak dimanfaatkan kegunaannya (Nurmala, 1998). Tanaman sorgum masih demikian kurang perkembangannya, padahal hasilnya dapat merupakan bahan pangan pengganti beras untuk di ekspor ( Kartasapoetra,1994). Sorgum memiliki potensi yang cukup besar untuk dapat dikembangkan di Indonesia. Tanaman ini toleransi terhadap kekeringan dan genangan, memiliki adaptasi yang luas dan dapat tumbuh di lahan yang kurang subur (Syam et al,1996).

Di berbagai belahan dunia, sorgum telah digunakan sejak lama sebagai bahan pangan terutama adalah pangan tradisional. Masyarakat Afrika dan India mengkonsumsi sorgum sejak ribuan tahun lalu dengan mengolahnya menjadi bubur dan panekuk. Di Afrika, terutama daerah tanzania, Afrika tengah dan Afrika Utara, sorgum juga digunakan sebagai bahan pembuat bir ( Dogget 1970). Sorgum telah dibudidayakan di Cina selama lebih dari 5000 tahun dan sekarang roti dengan bahan sorgum merupakan makanan paling penting di sebagian besar daerah kering di Afrika dan Asia (Bourman, 1985). Bahan pangan biji sorgum dapat diolah menjadi berbagai macam makanan. Tepung sorgum dapat diolah sebagai bahan dasar roti. Roti tawar yang terbuat dari tepung sorgum tidak berbeda teksturnya dibanding roti yang terbuat dari tepung terigu (Syam et al, 1996).

Pada umumnya sorgum ditanam sebagai tanaman sela pada padi gogo, jagung, kedelai atau tanaman palawija lainnya yang merupakan makanan tambahan. Sorgum jarang ditanam sebagai tanaman tunggal (Ismail dan Kodir,1977). Roesmarkam et al. (1993) menambahkan bahwa penanaman sorgum dapat 
ditumpangsarikan dengan palawija lainnya. Cara bercocok tanamnya hampir sama dengan jagung.

Sorgum mempunyai suatu kelebihan dibanding tanaman serealia lainnya dalam hal ketahanan terhadap kekeringan (Ismail dan Kodir, 1977). Roesmarkam et al (1993) menambahkan bahwa tanaman sorgum toleran terhadap kekeringan dan genangan,memiliki adaptasi yang luas dan dapat tumbuh dengan baik dilahan yang kurang subur.

Suatu usahatani pada dasarnya adalah suatu kegiatan yang diorganisasikan oleh seorang petani sebagai unit pengambilan keputusan untuk menghasilkan produk tanaman dan atau hewan guna mencapai tujuan dan kepuasan petani. Jadi usahatani merupakan suatu sistem yang berorientasi pada tujuan petani,dimana tujuan tersebut dapat bermacam-macam (Woerman, 1980).

Suatu usahatani merupakan agroekosistem yang unik: suatu kombinasi sumber-daya fisik dan biologis seperti bentuk-bentuk lahan, tanah, air, tumbuhan (tumbuhan liar, pepohonan, tanaman budidaya) dan hewan (liar dan dipelihara). Dengan mempengaruhi komponenkomponen agroekosistem ini dan interaksinya, rumah tangga petani mendapatkan hasil atau produk seperti tanaman, kayu dan hewan (Reijntjes et al., 1999).

Untuk menjaga proses produksi terus berlangsung, rumah tangga tani membutuhkan input, misalnya benih, unsur hara dan air. Input dalam adalah input yang diambil dari usahatani itu sendiri, misalnya sinar matahari, air hujan, sedimen, nitrogen yang diikat dari udara; atau yang dihasilkan sendiri, misalnya tenaga hewan, kayu, pupuk kandang, sisa tanaman, pupuk hijau, pakan ternak, tenaga kerja keluarga dan pengalaman-pengalaman belajar. Input luar adalah input yang diperoleh dari luar usahatani, misal informasi, tenaga buruh, bahan bakar minyak, pupuk buatan, biosida kimia, benih dan anakan unggul, air irigasi, alat-alat, mesin dan jasa (Reijntjes et al, 1999).

Secara garis besar ada dua bentuk usahatani yang telah dikenal yaitu usahatani keluarga (family farm) dan perusahaan pertanian (plantation,estate,enterprise). Pada umumnya yang dimaksud dengan usahatani adalah usaha keluarga sedangkan yang lain adalah perusahaan pertanian (Suratiyah,2011).

Dalam mengusahakan usahataninya,petani mengeluarkan biaya dan memperoleh pendapatan. Menurut Soekartawi et. al. (2011), biaya usahatani didefinisikan sebagai nilai semua masukan yang habis terpakai atau dikeluarkan di dalam produksi, tetapi tidak termasuk tenaga kerja keluarga petani. Soekartawi (2006) mengemukakan bahwa biaya usahatani dapat diklasifikasikan menjadi dua yaitu :

\section{Biaya tetap $(\mathrm{FC}=$ fixed cost $)$}

Biaya tetap didefinisikan sebagai biaya yang relative tetap jumlahnya, dan terus dikeluarkan walaupun produksi yang diperoleh banyak atau sedikit. Jadi besarnya biaya tetap tidak tergantung pada besar kecilnya produksi yang diperoleh. Contoh biaya tetap antara lain : pajak,sewa tanah,alat pertanian,iuran irigasi.

\section{Biaya variable ( $\mathrm{VC}=$ variable cost $)$}

Biaya variable didefinisikan sebagai biaya yang besar kecilnya dipengaruhi oleh produksi yang diperoleh, sehingga biaya ini sifatnya berubah-ubah tergantung dari besar kecilnya produksi yang diinginkan. Contoh biaya variable adalah biaya untuk sarana produksi meliputi biaya tenaga kerja, dan input (bibit, pupuk, pestisida).

Menurut Soekartawi (2006) rumus menghitung biaya usahatani adalah :

$$
\mathrm{TC}=\mathrm{FC}+\mathrm{VC}
$$

Keterangan :

$\mathrm{TC}=$ biaya total usahatani

$\mathrm{FC}=$ biaya tetap

$\mathrm{VC}=$ biaya variable

Menurut Soekartawi et. al. (2011) konsep penerimaan, biaya dan pendapatan sangat erat kaitannya dengan penampilan usahatani. Penerimaan didefinisikan sebagai nilai produk total usahatani dalam jangka waktu tertentu, baik yang dijual maupun tidak dijual. Jangka waktu pembukuan umumnya setahun dan mencakup semua produk yang dijual, dikonsumsi rumah tangga petani, digunakan dalam usahatani untuk bibit atau pakan ternak, digunakan untuk pembayaran, dan/atau disimpan digudang. Setelah diketahui jumlah penerimaan dan biaya 
usahatani, maka pendapatan usahatani dapat dihitung. Pendapatan usahatani adalah selisih antara penerimaan dan semua biaya. Menurut Suratiyah (2011), untuk menghitung pendapatan usahatan dikenal dua pendekatan yaitu :

\section{a. Income Approach}

Pada pendekatan ini pendapatan dapat dibedakan ke dalam dua hal, yaitu pendapatan kotor dan pendapatan bersih. Pendapatan kotor memiliki pengertian yang sama dengan penerimaan, yaitu jumlah produk yang dihasilkan pada suatu periode produksi dikalikan dengan harga per satuan produk tersebut. Pendapatan kotor dapat diperhitungkan dengan rumus :

$$
\mathrm{TR}=\mathrm{Y} \cdot \mathrm{P}_{\mathrm{y}}
$$

Keterangan :

TR : total revenue (pendapatan kotor total)

$\mathrm{Y} \quad$ : jumlah produksi

$\mathrm{P}_{\mathrm{y}} \quad$ : harga per satuan produk

Pendapatan bersih dalam usahatani merupakan selisih antara nilai output dengan semua biaya yang dikeluarkan secara nyata (TC eksplisit) dalam suatu periode produksi. Pendapatan bersih ini diperhitungkan dengan rumus :

$$
\mathrm{I}=\mathrm{TR}-\mathrm{TC} \text { (eksplisit) }
$$

Keterangan :

I : pendapatan bersih

TR : pendapatan kotor

TC : biaya total

\section{b. Profit Approach}

Keuntungan merupakan selisih antara nilai output dengan semua biaya yang dikeluarkan baik secara nyata (eksplisit) maupun tidak nyata (implisit). Keuntungan dapat dirumuskan sebagai berikut :

$$
\Pi=\mathrm{TR}-\mathrm{TC} \text { (ekplisit + implisit) }
$$

Keterangan :

$\Pi$ : keuntungan

TR : pendapatan kotor

TC : total biaya ( ekplisit + implisit)

\section{METODE PENELITIAN}

Metode dasar yang digunakan dalam penelitian ini adalah metode deskriptif-analitis yaitu metode penelitian yang memusatkan pada pemecahan masalah-masalah aktual yang ada pada masa sekarang. Data yang dikumpulkan mula-mula disusun, dijelaskan, kemudian dianalisis (Surachmad,1990).

Penelitian ini dilakukan di Kecamatan Wonosari Kabupaten Gunungkidul yang meliputi satu desa. Lokasi penelitian ditentukan secara purposive. Menurut Sandjaja (2006) pengertian purposive adalah berdasarkan keputusan subyektif peneliti yang didasarkan pada pertimbangan-pertimbangan tertentu. Pada cara ini peneliti mula-mula mengidentifikasi semua karakteristik populasi yang hendak diteliti dan mempelajari karakteristik tadi. Daerah tersebut dipilih karena kecamatan Wonosari adalah salah satu kecamatan yang masih membudidayakan sorgum. Dari beberapa desa di kecamatan Wonosari, maka dipilih satu desa yaitu desa Wareng IV dikarenakan desa Wareng IV merupakan satu-satunya desa dikecamatan tersebut yang penduduknya masih menanam sorgum untuk menambah pendapatan.

Pengujian hipotesis faktor-faktor yang mempengaruhi pendapatan usahatani sorgum adalah dengan fungsi pendapatan Cobb-Douglas dengan metode OLS. Model yang digunakan dalam penelitian ini adalah sebagai berikut :

$\mathrm{Y}=\ln \propto+\beta_{1} \ln \mathrm{X}_{1}+\beta_{2} \ln \mathrm{X}_{2}+\beta_{3} \ln \mathrm{X}_{3}+\beta_{4} \ln$ $\mathrm{X}_{4}+\beta_{5} \ln \mathrm{X}_{5}+\beta_{6} \ln \mathrm{X}_{6}+\beta_{7} \ln \mathrm{X}_{7}+\mathrm{e}$

Keterangan :

$\mathrm{Y}=$ Pendapatan usahatani sorghum

$\mathrm{X}_{1}=$ Luas lahan (Ha)

$\mathrm{X}_{2} \quad$ = Harga bibit yang dinormalkan (Rp)

$\mathrm{X}_{3}=$ Harga pupuk Urea yang dinormalkan (Rp)

$\mathrm{X}_{4}=$ Harga pupuk TSP yang dinormalkan (Rp)

$\mathrm{X}_{5}=$ Harga pupuk kandang yang dinormalkan (Rp)

$\mathrm{X}_{6}=$ Harga pupuk Ponska yang dinormalkan (Rp)

$\mathrm{X}_{7}=$ Harga tenaga kerja luar keluarga yang dinormalkan (Rp)

e $\quad=$ kesalahan (error)

Pengujian kemudian dilanjutkan dengan uji normalitas dan uji asumsi klasik regresi linier 
berganda. Kemudian dilanjutkan dengan pengujian distribusi pendapatan petani sorgum yang dilakukan dengan menggunakan rumus gini ratio :

$$
\mathrm{GR}=\sum_{j=1}^{k} \frac{Y j+Y j-1}{k}
$$

Keterangan :

$\mathrm{Yj}=$ presentase kumulatif pendapatan yang diterima sampai kelompok ke-j

$\mathrm{Yj}$-1 = presentase kumulatif pendapatan yang diterima sampai kelompok sebelumnya

$\mathrm{K}=$ jumlah kelompok (kelas)

\section{HASIL DAN PEMBAHASAN}

\section{A. Penerimaan, Biaya dan Pendapatan} Usahatani Sorgum

Pendapatan yang diperoleh petani merupakan kriteria untuk menentukan tingkat
Pendapatan usahatani sorgum terbilang sangat kecil karena tanaman sorgum ditanam untuk mengisi kekosongan lahan pada musim kering kedua. Hasil panen yang berupa biji dijual untuk pakan burung sedangkan hasil dalam bentuk batang sebagian digunakan untuk pakan ternak dan sebagian lagi dijual. Sedangkan penerimaan usahatani sorgum per hektar adalah Rp 2.754.794 dan pendapatan usahatani sorgum per hektar adalah Rp 1.973.144.

\section{B. Kontribusi Pendapatan Usahatani Sorgum Terhadap Pendapatan Total Petani}

Pendapatan total keluarga tani berasal dari usahatani dan luar usahatani. Pendapatan yang diperoleh merupakan pendapatan seluruh anggota rumahtangga tani (termasuk istri dan anak). Pendapatan usahatani adalah pendapatan yang

Tabel 1. Penerimaan, Biaya dan Pendapatan Usahatani Sorgum

\begin{tabular}{|l|r|r|}
\hline \multicolumn{1}{|c|}{ Keterangan } & \multicolumn{1}{|c|}{ Per Usahatani } & \multicolumn{1}{c|}{ Per Hektar } \\
\hline Penerimaan Total Usahatani Sorgum (a) & & 1.480 .000 \\
\hline Biji Sorgum (Rp) & 236.800 & 1.274 .794 \\
\hline Batang Sorgum (Rp) & 203.967 & \\
\hline Biaya Total (b) & & 40.313 \\
\hline Benih (Rp) & 6.450 & 103.125 \\
\hline Pupuk Urea (Rp) & 16.500 & 29.794 \\
\hline Pupuk TSP (Rp) & 4.767 & 103.000 \\
\hline Pupuk Kandang (Rp) & 16.480 & 21.669 \\
\hline Pupuk Ponska (Rp) & 3.467 & 28.544 \\
\hline Lain-lain (Rp) & 4.567 & 455.206 \\
\hline Tenaga kerja Luar Keluarga (Rp) & 72.833 & 1.973 .144 \\
\hline Pendapatan Usahatani Sorgum (a-b) & 315.703 & \\
\hline
\end{tabular}

Sumber : Analisis Data primer 2013

keberhasilan usahatani dalam menjalankan proses produksi. Pendapatan adalah selisih antara penerimaan dengan biaya yang dikeluarkan. Dalam menjalankan usahatani ada beberapa hal yang perlu diperhatikan yaitu biaya, penerimaan dan pendapatan usahatani. Tabel penerimaan, biaya dan pendapatan usahatani di lokasi penelitian disajikan pada tabel 1 .

Dari tabel 1. dapat diketahui bahwa penerimaan total usahatani sorgum adalah $\mathrm{Rp}$ 440.767 dan total biaya usahatani sorgum sebesar Rp 125.063. Pendapatan usahatani sorgum adalah selisih dari penerimaan usahatani sorgum dan biaya yang dikeluarkan dalam pelaksanaan usahatani sorgum yaitu, sebesar Rp 315.703. berasal dari kegiatan menggarap lahan yang dimiliki atau disewa. Pendapatan luar usahatani adalah pendapatan yang diperoleh dari buruh dan kegiatan non pertanian. Pendapatan total keluarga dapat dilihat pada tabel 2.

Dari tabel 2 dapat diketahui bahwa pendapatan paling besar adalah pendapatan luar usahatani yaitu sebesar Rp 9.849.333 dan pendapatan yang paling besar setelah pendapatan luar usahatani adalah pendapatan usahatani selain sorgum yaitu sebesar Rp 5.123.325 sedangkan usahatani sorgum hanya sebesar $\mathrm{Rp} 315.703$. sumbangan masing-masing usaha dapat dilihat pada gambar 1. Di bawah ini : 
Tabel 2. Pendapatan Total Keluarga

\begin{tabular}{|l|r|}
\hline \multicolumn{1}{|c|}{ Keterangan } & \multicolumn{1}{|c|}{ Nilai } \\
\hline Pendapatan Usahatani Sorgum (a) & 315.703 \\
\hline Pendapatan Usahatani Selain Sorgum & 4.489 .056 \\
\hline Usahatani Padi & 634.269 \\
\hline Usahatani Jagung & 5.123 .325 \\
\hline Total Pendapatan Usahatani Selain Sorgum (b) & 2.000 .000 \\
\hline Pendapatan Luar Usahatani & 4.913 .333 \\
\hline Buruh Pabrik & 800.000 \\
\hline Karyawan Swasta & 360.000 \\
\hline Wiraswasta & 1.776 .000 \\
\hline Buruh Tani & 9.849 .333 \\
\hline Dagang & 5.439 .028 \\
\hline Total pendapatan Luar usahatani $(\mathrm{c})$ & 15.288 .361 \\
\hline Pendapatan Total usahatani $(\mathrm{a}+\mathrm{b})$ & \\
\hline Pendapatan Total Keluarga $(\mathrm{a}+\mathrm{b}+\mathrm{c})$ & \\
\hline
\end{tabular}

Sumber : Analisis Data primer 2013

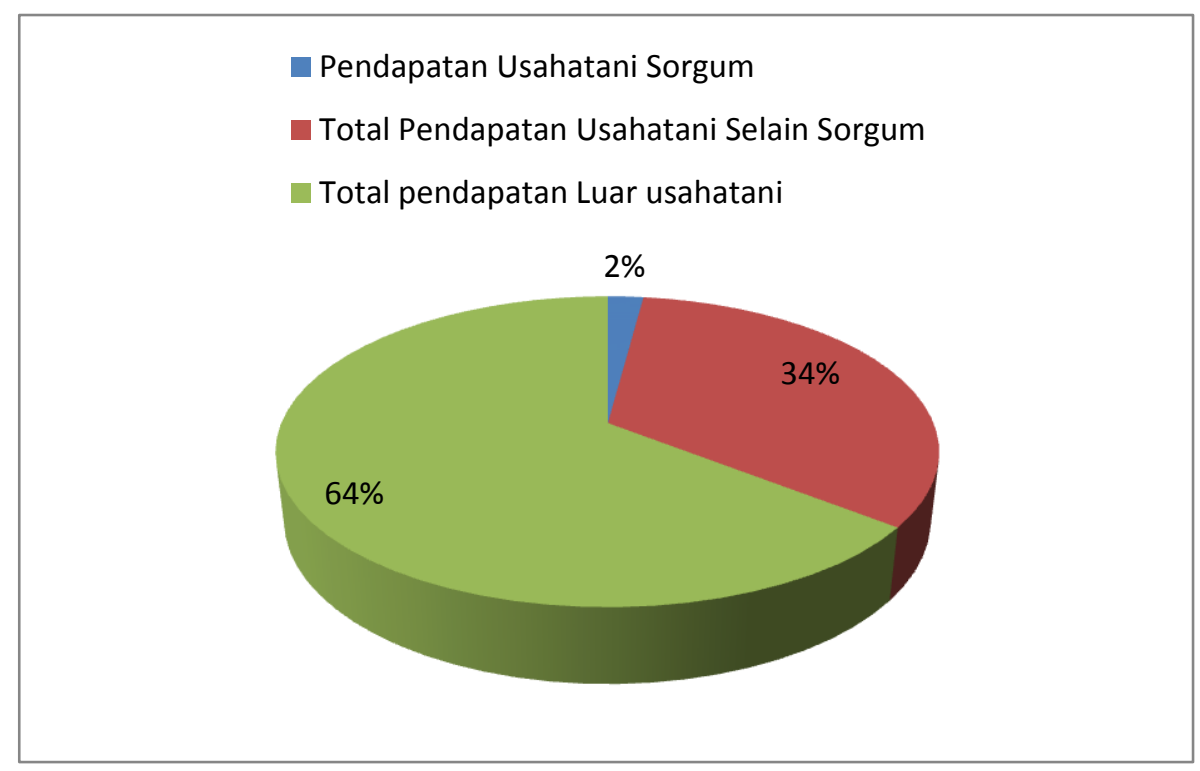

Gambar 1. Kontribusi Pendapatan Total Keluarga

Mengacu pada gambar 1, sumbangan terbesar perekonomian total keluarga tani berasal dari pendapatan luar usahatani. Sumbangan tersebut sebesar $64 \%$. Pendapatan luar usahatani memiliki sumbangan paling besar dikarenakan petani yang memiliki pekerjaan sampingan seperti wiraswasta, dagang, buruh pabrik,buruh tani dan PNS. Pekerjaan sampingan ini dilakukan untuk memenuhi kebutuhan sehari-hari petani. Sumbangan yang berasal dari usahatani selain sorgum yaitu usahatani padi dan usahatani jagung sebesar 34\%. Hal ini dikarenakan padi dan jagung adalah komoditas yang ditanam petani untuk menambah pendapatan rumahtangganya, sehingga penggunaan sarana produksi dan tenaga kerja digunakan secara maksimal untuk mendapat hasil yang maksimal. Pendapatan usahatani sorgum memiliki kontribusi sebesar $2 \%$ dari pendapatan total keluarga, karena sorgum ditanam untuk mengisi kekosongan lahan pada musim kering kedua, dan bijinya dijual untuk menambah pendapatan petani.

\section{Faktor-faktor yang Mempengaruhi Pendapatan Usahatani Sorgum}

Hipotesis dalam penelitian ini adalah “ diduga faktor-faktor yang mempengaruhi pendapatan usahatani sorgum di Kabupaten Gunungkidul adalah luas lahan, harga benih, harga pupuk urea, harga pupuk TSP, harga pupuk kandang, harga pupuk ponska, dan harga tenaga kerja luar keluarga." Untuk membuktikan 
hipotesis tersebut dilakukan analisis regresi linier berganda berdasarkan data primer.

Jumlah sampel pada penelitian ini adalah 30 petani responden. Hasil analisis regresi menunjukkan bahwa nilai adj $\mathrm{R}^{2}$ adalah 0,701 . Artinya, pendapatan usahatani sorgum $70,1 \%$ dapat dijelaskan oleh faktor-faktor yang dianalisis dan 29,9\% dijelaskan oleh faktor lain yang tidak dianalisis. Faktor yang dianalisis mempengaruhi pendapatan usahatani sorgum adalah luas lahan,harga benih,harga pupuk urea, harga pupuk TSP, harga pupuk kandang, harga pupuk ponska, harga tenaga kerja luar keluarga.

Nilai $F$ hitung yang diperoleh dari hasil analisis data lebih besar dari $\mathrm{F}$ tabel $(2,66)$ pada tingkat kesalahan $1 \%$ yaitu 8,689 . Hal ini berarti bahwa variabel independen yaitu luas lahan,harga benih,harga pupuk urea,harga pupuk TSP, harga pupuk kandang, harga pupuk ponska, harga tenaga kerja luar keluarga secara bersama-sama berpengaruh pada tingkat kesalahan $1 \%$ terhadap variabel dependen yaitu pendapatan usahatani sorgum.

Konstanta memiliki signifikansi 0,00 sehingga ketika variabel independen yaitu luas lahan, harga benih, harga pupuk urea, harga pupuk TSP, harga pupuk kandang, harga pupuk kedua adalah luas lahan dan harga bibit. Penjelasan dari faktor-faktor yang berpengaruh signifikan adalah :

\section{Luas lahan}

Dari hasil regresi didapat hasil probabilitas variabel luas lahan sebesar 0,000 dimana nilai itu lebih kecil dari nilai $\alpha(\alpha=1 \%)$ sehingga variabel luas lahan berpengaruh secara signifikan terhadap pendapatan petani sorgum. Sedangkan dari nilai koefisien regresi sebesar 0,983 dapat diartikan bahwa setiap penambahan $1 \%$ satuan luas lahan akan meningkatkan pendapatan usahatani sorgum sebesar $0,983 \%$.

Luas lahan berpengaruh secara signifikan karena semakin besar luas lahan maka tanaman sorgum yang bisa ditanam akan semakin banyak sehingga produksi akan meningkat. Dengan meningkatnya produksi maka penerimaan usahatani sorgum akan meningkat yang akan diikuti dengan meningkatnya pendapatan.

\section{Harga benih}

Dari hasil regresi didapat hasil probabilitas variabel harga benih sebesar 0,000 dimana nilai itu lebih kecil dari nilai $\alpha(\alpha=1 \%)$ sehingga variabel harga benih berpengaruh secara signifikan terhadap pendapatan petani

Tabel 3. Hasil Analisis Faktor-Faktor Yang Mempengaruhi Pendapatan Usahatani Sorgum.

\begin{tabular}{|l|r|r|r|}
\hline \multicolumn{1}{|c|}{ Variabel } & Koefisien & \multicolumn{1}{c|}{ t-hitung } & \multicolumn{1}{c|}{ Prob } \\
\hline Konstanta & $7,481^{* * *}$ & 4,403 & 0,000 \\
\hline $\ln$ (luas lahan) & $0,983^{* * *}$ & 5,768 & 0,000 \\
\hline $\ln$ (harga benih) & $0,903^{* * *}$ & 4,751 & 0,000 \\
\hline $\ln$ (harga pupuk Urea) & $-0,002$ & $-0,253$ & 0,803 \\
\hline $\ln$ (harga pupuk TSP) & 0,023 & 0,838 & 0,414 \\
\hline ln (harga pupuk kandang) & $-0,002$ & $-0,237$ & 0,815 \\
\hline ln (harga pupuk ponska) & 0,009 & 0,344 & 0,735 \\
\hline ln (harga TKLK) & 0,016 & 0,872 & 0,396 \\
\hline F hit & $8,689^{* * *}$ & & 0,001 \\
\hline Adj R & 0,701 & & \\
\hline
\end{tabular}

Sumber : Data Primer Diolah 2013

Keterangan : *** : berpengaruh nyata pada tingkat kesalahan $1 \%$

** : berpengaruh nyata pada tingkat kesalahan 5\%

* : berpengaruh nyata pada tingkat kesalahan $10 \%$

ponska dan harga tenaga kerja luar keluarga dihilangkan atau bernilai 0 petani akan tetap mendapat pendapatan sebesar Rp 1774,01.

Berdasarkan tabel 3, dapat dijelaskan bahwa faktor-faktor yang mempengaruhi pendapatan usahatani sorgum pada musim kering sorgum.sedangkan dari nilai koefisien regresi sebesar 0,903 dapat diartikan bahwa setiap penambahan $1 \%$ satuan harga benih akan meningkatkan pendapatan usahatani sorgum sebesar $0,903 \%$. 
Harga benih berpengaruh secara signifikan dan berpengaruh positif karena semakin besar harga benih, petani mempunyai kecenderungan untuk menggunakan hasil produksi sorgum sebagai benih, sehingga tidak ada pengeluaran untuk membeli benih dan mengakibatkan peningkatan pendapatan.

\section{Distribusi Pendapatan}

Distribusi pendapatan merupakan ukuran kemerataan pendapatan rumahtangga pada saat terjadi pertumbuhan ekonomi. Indikator yang sering digunakan untuk mengetahui kesenjangan distribusi pendapatan adalah gini ratio dan kriteria Oshima. Nilai gini ratio berkisar antara nol dan satu. Bila gini ratio sama dengan nol berarti distribusi pendapatan sangat merata karena setiap golongan penduduk menerima bagian pendapatan yang sama. Secara grafis ditunjukkan oleh berimpitnya kurva lorens dengan garis kemerataan sempurna. Namun bila gini rasio sama dengan satu menunjukkan bahwa terjadi kerimpangan distribusi pendapatan yang sempurna karena seluruh pendapatan hanya dinikmati oleh satu orang saja (Kuncoro, 1997).

\section{Indeks Gini}

Indeks Gini digunakan untuk mengetahui kategori ketimpangan distribusi pendapatan dalam suatu kelompok,dalam penelitian ini, indeks gini digunakan untuk mengetahui peranan pendapatan usahatani sorgum terhadap pendapatan total petani. Berdasarkan analisis yang dilakukan, besarnya nilai indeks gini pendapatan total petani dapat dilihat pada tabel 4 . dengan distribusi pendapatan total petani tanpa sorgum mempunyai ketimpangan sedang. Jika dilihat dari nilai indeks gini yang didapat dari hasil perhitungan, maka pendapatan total petani tanpa sorgum lebih besar daripada pendapatan total petani. Sehingga dapat diambil kesimpulan bahwa dengan usahatani sorgum tidak menyebabkan ketimpangan distribusi pendapatan rumahtangga tani di lokasi penelitian.

Usahatani sorgum mampu memperbaiki pendapatan usahatani tanpa sorgum, karena usahatani sorgum mempunyai peranan bagi rumahtangga tani, yaitu sebagai penyumbang struktur pendapatan rumahtangga tani. Pendapatan usahatani sorgum memberi sumbangan sebesar $2 \%$ dari pendapatan total petani. Walaupun kegiatan usahatani sorgum bukan merupakan kegiatan utama yang dilakukan oleh rumahtangga tani, tetapi dengan adanya usahatani sorgum dapat mempebaiki distribusi pendapatan rumahtangga tani dilokasi penelitian walaupun tidak signifikan.

\section{Kurva Lorenz}

Dari data analisis yang telah dihimpun pada tabel 4 maka dapat digambarkan kurva lorenz yang memperlihatkan tingkat kemerataan dan hubungan kuantitatif antara presentase penerima pendapatan dan presentase pendapatan yang diperoleh. Setiap titik pada garis diagonal menunjukkan kedudukan presentase penerima pendapatan. Titik tengah garis diagonal menunjukkan $50 \%$ dari pendapatan didistribusikan tepat untuk $50 \%$ dari jumlah

Tabel 4. Nilai Indeks Gini Pendapatan Rumahtangga Petani

\begin{tabular}{ccc}
\hline Sumber Pendapatan & Nilai Indeks Gini & Kategori Ketimpangan \\
\hline Pendapatan total petani & 0,427 & Ketimpangan sedang \\
Pendapatan total tanpa sorgum & 0,429 & Ketimpangan sedang \\
\hline
\end{tabular}

Sumber : Analisis Data Primer 2013

Berdasarkan analisis distribusi pendapatan yang dilakukan dengan menggunakan indeks gini (Gini ratio), maka dapat diketahui bahwa nilai indeks gini pendapatan total petani sebesar 0,427, nilai indeks gini pendapatan total tanpa sorgum sebesar 0,429. Berdasarkan kriteria Oshima (1976) dalam Supadi dan Nurmanaf (2004), distribusi pendapatan total petani sorgum mempunyai ketimpangan sedang, sama halnya penduduk. Jadi garis diagonal merupakan garis kemerataan sempurna dalam distribusi ukuran pendapatan.

Penggunaan kurva lorenz akan lebih informatif dalam menerangkan hubungan antara pendapatan yang didistribusikan pada populasi yang ada. Kurva Lorenz Distribusi Pendapatan petani Kabupaten Gunungkidul diperlihatkan pada gambar 2. 


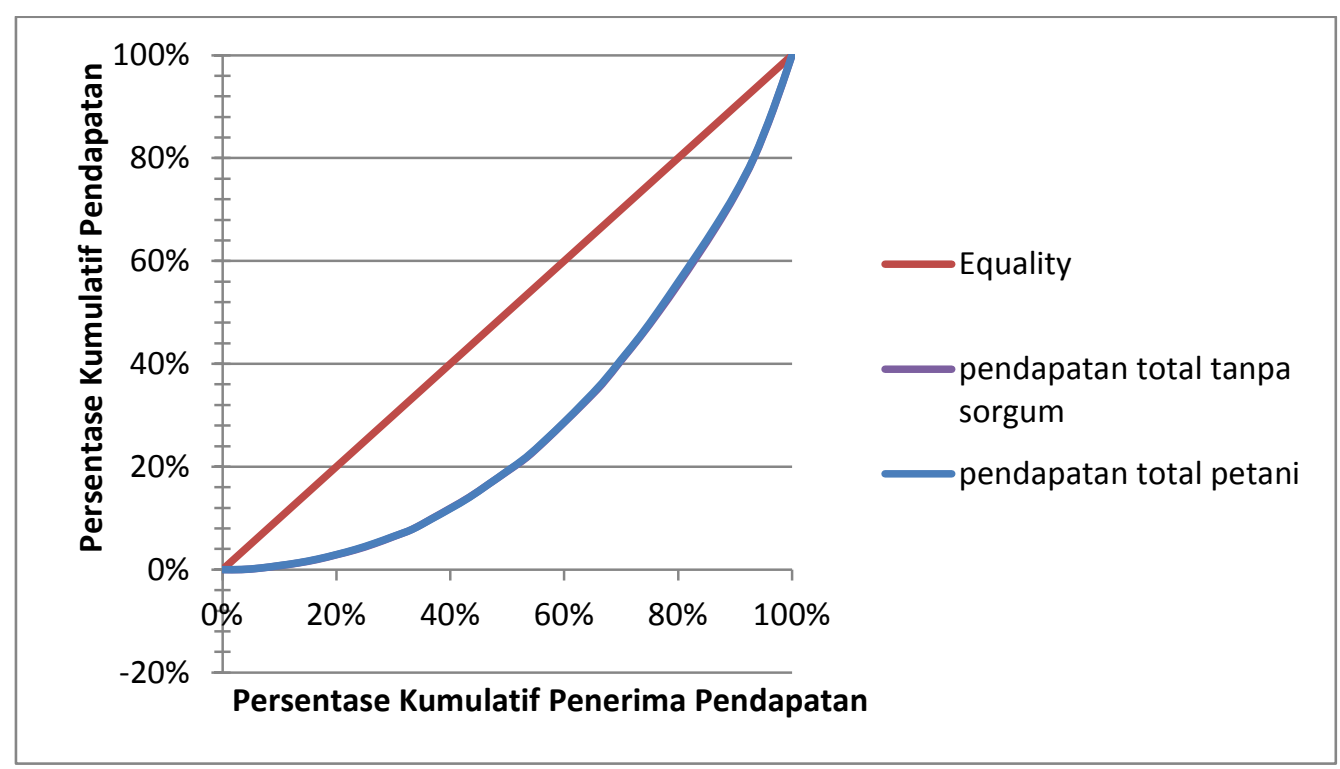

Gambar 2 .Kurva Lorenz Distribusi Pendapatan Petani Gunungkidul

Gambar 2 memperlihatkan bahwa garis pendapatan total petani hampir sama rata dengan garis pendapatan total petani tanpa sorgum. Hal ini menunjukkan bahwa pendapatan total petani tidak hampir sama distribusinya dengan pendapatan total petani tanpa sorgum.

Dari kedua ukuran distribusi pendapatan terlihat bahwa pendapatan total petani hampir sama jika dibandingkan dengan pendapatan total petani tanpa sorgum. Pendapatan total petani merupakan jumlah dari pendapatan usahatani non sorgum, pendapatan usahatani sorgum dan pendapatan luar usahatani. Berarti pendapatan usahatani sorgum tidak menyebabkan ketimpangan distribusi pendapatan usahatani.

Berdasarkan uraian tersebut maka hipotesis yang menyatakan bahwa distribusi pendapatan petani sorgum memiliki ketimpangan yang rendah ditolak.

Meskipun pendapatan rumahtangga tani yang berasal dari usahatani sorgum memberikan kontribusi yang paling kecil terhadap pendapatan total petani yaitu sebesar $2 \%$ dari pendapatan total petani namun dapat diketahui bahwa usahatani sorgum memiliki beberapa peranan penting diantaranya adalah:

a. Sebagai pakan ternak petani. Petani tidak perlu mengeluarkan biaya untuk pakan ternaknya karena sorgum yang ditanam dilahan dapat digunakan sebagai pakan ternak sehingga mengurangi pengeluaran atau biaya untuk pakan ternak.

b. Sebagai substitusi bahan pangan. Saat mengalami kesulitan pangan, petani dilokasi penelitian menggunakan sorgum sebagai bahan pangan selain ubi dan jagung. Sorgum dapat diolah menjadi kue tradisional ataupun sebagai campuran beras.

Pendapatan rumahtangga tani yang berasal dari pendapatan luar usahatani memberikan kontribusi yang paling besar terhadap pendapatan total petani yaitu sebesar $58 \%$ dari total pendapatan petani. Aktivitas luar usahatani mempunyai peran penting, yaitu sebagai penyusun struktur pendapatan rumahtangga tani. Di sektor luar usahatani, secara umum pendapatan pendapatan yang berasal dari swasta, wiraswasta, dagang, pegawai negeri dan buruh pabrik cukup berperan dalam menyumbang pendapatan rata-rata rumahtangga di daerah penelitian. Peranan pendapatan dari bekerja sebagai karyawan swasta cukup menonjol. Hal ini dikarenakan banyaknya penduduk usia produktif (16 - 64 tahun) yang merantau ke luar daerah dan menjadi karyawan swasta. Pekerjaan sebagai buruh pabrik juga merupakan pendapatan yang cukup berperan di sektor luar usahatani di daerah penelitian. Hal ini mudah dimengerti karena mengingat sektor ini merupakan salah satu sektor yang mudah diakses oleh semua 
lapisan rumah tangga karena memasuki sektor ini tidak dibutuhkan syarat ketrampilan khusus.

\section{KESIMPULAN DAN SARAN}

\section{A. Kesimpulan}

1. Faktor-faktor yang mempengaruhi pendapatan petani sorgum secara positif di Kabupaten Gunungkidul adalah luas lahan dan harga bibit.

2. Kontribusi pendapatan usahatani sorgum terhadap pendapatan total petani sangat kecil yaitu sebesar $2 \%$ dari total pendapatan petani.

3. Nilai indeks gini pendapatan total petani sebesar 0,427 dan nilai indeks gini pendapatan total petani tanpa sorgum adalah 0,429 yang termasuk dalam kategori ketimpangan sedang, sehingga usahatani sorgum tidak menyebabkan ketimpangan distribusi pendapatan petani.

\section{B. Saran}

1. Petani hendaknya lebih mengoptimalkan penggunaan lahan untuk usahatani sorgum agar hasil produksi yang diperoleh lebih optimal sehingga pendapatan rumahtangga tani meningkat.

2. Petani hendaknya lebih banyak menggunakan pupuk agak produksi lebih tinggi, sehingga dapat meningkatkan pendapatan rumahtangga tani.

3. pemerintah hendaknya lebih memberikan perhatian dalam pemasaran hasil panen sorgum agar petani dapat dengan mudah memasarkan atau menjual hasil panen sorgum kepada konsumen dengan harga yang sesuai.

\section{DAFTAR PUSTAKA}

DIY Agricenter. 2008. Teknologi Produksi Sorgum. Seksi Pengembangan teknologi dan Produksi Perbenihan tanaman Pangan. UPTD Balai Pengembangan Perbenihan tanaman Pangan dan Hortikultura (BP2APTP).

http://agricenter.hogjaprov.go.id/index.php ?action=generic_content.main\&id_gc $=315$

- Diakses tanggal 30 Agustus 2013. Yogyakarta.

Doggett, H. 1970. Sorghum. Longmans Green \& Co.Ltd. Cambridge, USA.
Ismail, G, I dan A, kodir. 1977. Cara Bercocok tanam sorghum. Buletin Teknik Lembaga Pusat Penelitian Pertanian Bogor (2).1-9.

Kartasapoetra, A.G. 1994. Teknologi Penanganan Pasca panen. PT Rineka Cipta. Jakarta.

Leonard, W. H. \& Martin, J. H. 1963. Cereal Crops. The Macmillan Company, USA, Pp679-735.

Martin, J. H. 1970. History and classification of sorghum. In J.S. Wall and W.M.Ross (Eds). Sorhum production and utilization. The Avi Publishing Co.Inc.Westport Connecticut. 702 p.

Nurmala, Tati. 1998. Serealia Sumber karbohidrat Utama Cetakan Pertama. PT Rineka Cipta. Jakarta reddy, V.S. Blumm dan W. D. Dar. 2007 Sweet Sorgum for Bioetanol. Makalah dalam Workshop "Peluang dan Tantangan Sorgum Manis sebagai Bahan Baku Bioetanol". Dirjen Perkebunan, Departemen Pertanian. Jakarta. Hal. 8.

Poehlman, J, M. 1988. Breeding Field Crops. Second ed. Avi Publishing Company, Inc. Westport, Connecticut.486 p.

Roesmarkam, S., Subandi, dan E. Muchlis.1985. Hasil penelitian pemuliaan sorgum. Risalah Rapat Teknis Pusat Penelitian dan Pengembangan Pertanian Bogor. 155-160.

Sumarno dan S. Karsono. 1996. Perkembangan produksi sorgum di dunia dan penggunaannya. Risalah Simposium prospek Tanaman Sorgum untuk Pengembangan Agroindustri, 17-18 Januari 1995. Edisi Khusus Balai Penelitian Tanaman Kacang-kacangan dan Umbi-umbian No. 4-1996: 13-24.

Suprapto dan R. Mudjisihene. 1987. Budidaya dan Pengolahan Sorgum. Jakarta : Penebar Swadaya.

Syam, M., hermanto dan A. Musaddad. 1996. Kinerja Penelitian Tanaman Pangan, prosiding Simposium penelitian Tanaman Pangan III, Buku 4. Pusat Penelitian dan Pengembangan tanaman Pangan Bogor.

Steenis, C. G G.J. Van. 1975. Flora. Pradnya paramita. Jakarta. 495 hal.

Wardhani, N.K. 1996. Sorghum vulgare sudanense sebagai alternatif penyediaan hijauan pakan. Risalah Simposium Prospek Tanaman Sorgum untuk Pengembangan 